\title{
Vanillic Acid Alleviates Acute Myocardial Hypoxia/Reoxygenation Injury by Inhibiting Oxidative Stress
}

\author{
Xiuya Yao, ${ }^{1,2}$ Shoufeng Jiao, ${ }^{3}$ Mingming Qin, ${ }^{1}$ Wenfeng Hu, ${ }^{1}$ Bo Yi $\mathbb{D},{ }^{4}$ and Dan Liu $\mathbb{D}{ }^{1}$ \\ ${ }^{1}$ Jiangxi Provincial Key Laboratory of Basic Pharmacology, Nanchang University, School of Pharmaceutical Science, \\ Nanchang 330006, China \\ ${ }^{2}$ Department of Pharmacy, Changzhou Maternal and Child Health Care Hospital, Changzhou 213000, China \\ ${ }^{3}$ Department of Pharmacy, The First Affiliated Hospital of Nanchang University, Nanchang 330006, China \\ ${ }^{4}$ Second Abdominal Surgery Department, Jiangxi Province Tumor Hospital, Nanchang 330029, China \\ Correspondence should be addressed to Bo Yi; yibo790508@163.com and Dan Liu; liudan1201jx@163.com
}

Received 25 November 2019; Accepted 23 March 2020; Published 21 April 2020

Guest Editor: Aleksandar Kibel

Copyright (c) 2020 Xiuya Yao et al. This is an open access article distributed under the Creative Commons Attribution License, which permits unrestricted use, distribution, and reproduction in any medium, provided the original work is properly cited.

\begin{abstract}
Oxidative stress is an important factor of myocardial hypoxia/reoxygenation $(\mathrm{H} / \mathrm{R})$ injury. Our research focuses on how to reduce the cardiac toxicity caused by oxidative stress through natural plant extracts. Vanillic acid (VA) is a phenolic compound found in edible plants and rich in the roots of Angelica sinensis. Experimental studies have provided evidence for this compound's effectiveness in cardiovascular diseases; however, its mechanism is still unclear. In this study, molecular mechanisms related to the protective effects of VA were investigated in H9c2 cells in the context of $\mathrm{H} / \mathrm{R}$ injury. The results showed that pretreatment with VA significantly increased cell viability and decreased the percentage of apoptotic cells, as well as lactate dehydrogenase and creatine phosphokinase activity, in the supernatant, accompanied by reduced levels of reactive oxygen species and reduced caspase-3 activity. VA pretreatment also restored mitochondrial membrane potentials. Moreover, preincubation with VA significantly attenuated mitochondrial permeability transition pore activity. VA administration upregulated adenosine monophosphate-activated protein kinase $\alpha 2(\mathrm{AMPK} \alpha 2)$ protein expression, and interestingly, pretreatment with AMPK $\alpha 2$ siRNA lentivirus effectively attenuated the cardioprotective effects of VA in response to H/R injury.
\end{abstract}

\section{Introduction}

Myocardial hypoxia/reoxygenation (H/R) injury leads to significant morbidity and mortality [1], and oxidative stress is one of the most important factors causing cardiac toxicity. Natural plant extracts have the advantages of few side effects and easy access. Therefore, our research focuses on the use of natural plant extracts to protect the heart against oxidative stress, thereby reducing cardiac toxicity caused by I/R injury. Vanillic acid (VA) is a phenolic compound found in secondary plant products with the molecular formula $\mathrm{C}_{8} \mathrm{H}_{8} \mathrm{O}_{4}$. VA is widely used in the food industry as flavouring agent, food additive, and preservative. We detected VA in various foods, such as herbs, tea, coffee, wine, and beer [2-7]. VA possesses powerful antioxidant functions, antihypotensive effects, cardioprotective effects, hepatoprotective effects, and antiapoptotic activities [8-11].

Adenosine monophosphate-activated protein kinase (AMPK) is a stress responsive kinase that modulates a number of physiologically and metabolically significant pathways, including apoptosis, energy dynamic balance, and cellular metabolism [12]. AMPK ameliorates cellular antioxidant enzyme systems, such as manganese superoxide dismutase (Mn-SOD) and catalase, consequently reducing oxidant-induced injury [13].

Accordingly, we hypothesized that VA exerts a protective effect against hypoxia/reoxygenation (H/R) injury, which might be related to the AMPK signalling pathway. Therefore, the present study is aimed at addressing the following aims: (1) determine whether VA pretreatment protects H9c2 
cells from hypoxia/reoxygenation (H/R) injury and (2) explore the underlying protective mechanisms of VA on hypoxia/reoxygenation $(\mathrm{H} / \mathrm{R})$ injury in $\mathrm{H} 9 \mathrm{c} 2$ cells.

\section{Materials and Methods}

2.1. Reagents. VA (purity: $>98 \%$ ) was purchased from Sigma Chemical Co. (St. Louis, MO, USA). The AMPK $\alpha 2$-siRNA lentivirus was purchased from Genechem Co. (Shanghai, China).

2.2. Cell Culture. Embryonic rat heart-derived H9c2 cells were purchased from the Chinese Academy of Sciences cell bank. $\mathrm{H} 9 \mathrm{c} 2$ cells were incubated at $37^{\circ} \mathrm{C}$ in a $5 \% \mathrm{CO}_{2}$ incubator Forma $^{\mathrm{TM}} 310$, Thermo Fisher, USA) with high glucose (4.5 g/l glucose) DMEM (Solarbio, Beijing, China) by adding $13 \%$ FBS (foetal bovine serum, WISENT, Canada) and antibiotics $(100 \mathrm{U} / \mathrm{ml}$ penicillin and $100 \mu \mathrm{g} / \mathrm{ml}$ streptomycin, Solarbio, Beijing, China). The hypoxia/reoxygenation (H/R) cell model was set up to imitate an ischaemia/reperfusion (I/R) model in vitro [14-17]. Briefly, after different pretreatments, H9c2 cells were cultured in hypoxic solution (sodium lactate $40 \mathrm{mM}, \mathrm{NaH}_{2} \mathrm{PO}_{4} 0.9 \mathrm{mM}, \mathrm{NaHCO}_{3} 6 \mathrm{mM}, \mathrm{MgSO}_{4}$ $1.2 \mathrm{mM}$, HEPES $20 \mathrm{mM}, \mathrm{CaCl}_{2} 1.8 \mathrm{mM}, \mathrm{NaCl} 98.5 \mathrm{mM}, \mathrm{KCl}$ $10 \mathrm{mM}, \mathrm{pH} 6.8$ ) and incubated at $37^{\circ} \mathrm{C}$ with $5 \% \mathrm{CO}_{2}$ and $0.1 \% \mathrm{O}_{2}$ in a hypoxic chamber (Proox model C21, BioSpherix Ltd., USA) for $3 \mathrm{~h}$. H9c2 cells were subsequently cultured in reoxygenation solution (glucose $5.5 \mathrm{mM}, \mathrm{NaH}_{2} \mathrm{PO}_{4} 0.9 \mathrm{mM}$, $\mathrm{NaHCO}_{3} 20 \mathrm{mM}, \mathrm{MgSO}_{4} 1.2 \mathrm{mM}$, HEPES $20 \mathrm{mM}, \mathrm{CaCl}_{2}$ $1.8 \mathrm{mM}, \mathrm{NaCl} 129.5 \mathrm{mM}, \mathrm{KCl} 5 \mathrm{mM}, \mathrm{pH} 7.4)$ and incubated at $37^{\circ} \mathrm{C}$ and $95 \% \mathrm{O}_{2} / 5 \% \mathrm{CO}_{2}$ in a reoxygenation chamber for $2 \mathrm{~h}$. All experiments were performed in triplicate.

2.3. Experimental Protocol. Cultured H9c2 cells were randomly divided into the following experimental groups:

(1) Control group comprised H9c2 cells that were maintained in normoxic conditions with 95\% air and 5\% $\mathrm{CO}_{2}$ in complete medium for $5 \mathrm{~h}$

(2) $\mathrm{H} / \mathrm{R}$ group comprised conditions described in Section 2.2

(3) $\mathrm{VA}+\mathrm{H} / \mathrm{R}$ group comprised $\mathrm{H} 9 \mathrm{c} 2$ cells that were pretreated with $1.00 \mathrm{mM}$ VA $24 \mathrm{~h}$ before H/R treatment

(4) $\mathrm{VA}+\mathrm{NC}+\mathrm{H} / \mathrm{R}$ group included $\mathrm{H} 9 \mathrm{c} 2$ cells that were pretreated with $1.00 \mathrm{mM}$ VA $24 \mathrm{~h}$ before H/R treatment and the negative lentivirus $48 \mathrm{~h}$ before $H / R$ treatment

(5) $\mathrm{VA}+\mathrm{AMPK} \alpha 2$-siRNA $+\mathrm{H} / \mathrm{R}$ group comprised $\mathrm{H} 9 \mathrm{c} 2$ cells that were pretreated with $1.00 \mathrm{mM} \mathrm{VA} 24 \mathrm{~h}$ before $\mathrm{H} / \mathrm{R}$ treatment and the lentivirus AMPK $\alpha 2$ siRNA $48 \mathrm{~h}$ before $\mathrm{H} / \mathrm{R}$ treatment

2.4. Cell Viability Assays. The viability of $\mathrm{H} 9 \mathrm{c} 2$ cells was determined using the 3-(4,5-dimethylthiazol-2-yl)-5-(3-carboxymethoxyphenyl)-2-(4-sulfophenyl)-2H-tetrazolium (MTS) kit. MTS (Promega, USA) produces a dark blue formazan product when incubated with living cells. H9c2 cells were trypsinized, counted, and seeded in 96-well plates at a density of $1 \times 10^{4}$ cells per well. Following incubation and different treatments, H9c2 cells were treated with $20 \mu \mathrm{l}$ MTS $(5 \mathrm{mg} / \mathrm{ml})$ in $100 \mu \mathrm{l}$ medium for $2 \mathrm{~h}$ at $37^{\circ} \mathrm{C}$. After $2 \mathrm{~h}$, the optical density (OD) of each well was determined at a wavelength of $490 \mathrm{~nm}$ using a microplate reader (Bio-Rad 680, USA). H9c2 cell viability is indicated as a percentage of controls.

2.5. Assessment of LDH and CPK Activities. Lactate dehydrogenase ( $\mathrm{LDH})$ and creatine phosphate kinase (CPK) activities were determined using $\mathrm{LDH}$ and $\mathrm{CPK}$ commercial assay kits (Jiancheng Bioengineering Institute, Nanjing, China) according to the manufacturer's instructions [18]. H9c2 cell supernatants were collected after different treatments, and optical density (OD) was determined at a wavelength of $440 \mathrm{~nm}$ and $660 \mathrm{~nm}$ to measure $\mathrm{LDH}$ and CPK activities, respectively, using a microplate reader (Bio-Rad 680, USA).

2.6. Western Blot Analysis. H9c2 cells were washed using cold phosphate-buffered saline (PBS) three times, followed by lysis with Radio Immunoprecipitation Assay (RIPA) and phenylmethanesulfonyl fluoride (PMSF) buffer on ice for $10 \mathrm{~min}$. To remove insoluble material, extracts were centrifuged at $12,000 \mathrm{rpm}$ for $15 \mathrm{~min}$ at $4^{\circ} \mathrm{C}$. Total protein content was subsequently measured using the Bradford protein assay kit (Beyotime, Shanghai, China). Equal amounts of protein were electrophoresed on $10 \%$ sodium dodecyl sulfate polyacrylamide gel electrophoresis (SDS-PAGE) using a gel apparatus (Bio-Rad, USA). Gels were cut according to a prestained, dual color protein molecular weight marker followed by transfer to polyvinylidene fluoride (PVDF) membranes (Solarbio, Beijing, China) which were blocked with 5\% nonfat milk in TBST (Tris-Buffer Saline, $0.25 \%$ Tween-20) for $2 \mathrm{~h}$. Membranes were incubated with antibodies ( $1: 500$ dilution) for AMPK $\alpha 2$ (Abcam, USA) and $\beta$-actin (ZSGB-BIO, Beijing, China) overnight at $4^{\circ} \mathrm{C}$. Next, membranes were washed nine times for $10 \mathrm{~min}$ each in TBST (Tris-Buffer Saline, 0.25\% Tween-20). Then, the membranes were incubated with HRP-labelled IgG secondary antibodies for AMPK $\alpha 2$ (1:5000 dilution) (ZSGB-BIO, Beijing, China) and $\beta$-actin ( $1: 2000$ dilution) with shaking at room temperature for $2 \mathrm{~h}$. Next, membranes were washed six times for 10 min each in TBST. To detect the immune complexes, the enhanced chemiluminescence (ECL) method was used. To measure protein expression, densitometry analysis was employed using Image Lab software (Bio-Rad, USA). We used the ratio of the grey value of the target protein and the corresponding beta-actin protein for quantification and statistical analysis.

2.7. Determination of Reactive Oxygen Species (ROS) Levels. The fluorescence probe DCFH-DA (2,7-dichlorofluorescein diacetate) is converted to $\mathrm{DCFH}_{2}$ which is oxidized to DCF by ROS. DCF emits a green fluorescent signal that can be measured by flow cytometry. This assay was used according to the manufacturer's instructions. H9c2 cells were collected and incubated in a serum-free medium with a final concentration of $10 \mu \mathrm{M}$ DCFH-DA (KeyGEN BioTECH, Nanjing, China) at $37^{\circ} \mathrm{C}$ for $30 \mathrm{~min}$ in the dark. Fluorescence intensity 
of dichlorofluorescin (DCF) was measured by flow cytometry (Beckman Coulter, USA) at $488 \mathrm{~nm}$ excitation and at $525 \mathrm{~nm}$ emission. A.U. is the abbreviation for arbitrary units.

2.8. Measurement of Mitochondrial Membrane Potential $\left(\Delta \Psi_{m}\right)$. JC-1 $\left(5,5^{\prime}, 6,6^{\prime}\right.$-tetrachloro- $1,1^{\prime}, 3,3^{\prime}$-tetraethylbenzimidazolo carbocyanine iodide) is a dye that changes color from green to red when $\Delta \psi_{\mathrm{m}}$ increases. Mitochondrial membrane potential was measured using JC-1 (KeyGEN BioTECH, Nanjing, China) staining following the manufacturer's instructions. After washing twice with ice-cold PBS, $\mathrm{H} 9 \mathrm{c} 2$ cells were harvested and incubated with JC-1 solution at a final concentration of $200 \mu \mathrm{M}$ at $37^{\circ} \mathrm{C}$ for $20 \mathrm{~min}$ in the dark. Fluorescence was detected by flow cytometry (Beckman Coulter, USA) at excitation and emission wavelengths (ex/em) of $488 / 630 \mathrm{~nm}$ (red) and $488 / 530 \mathrm{~nm}$ (green). $\Delta \psi_{\mathrm{m}}$ was calculated as the red/green fluorescence ratio.

2.9. $\mathrm{Ca}^{2+}$-Induced Mitochondria Swelling. After different treatments, H9c2 cell mitochondria were extracted using the cell mitochondria isolation kit (KeyGEN BioTECH, Nanjing, China). Next, purified mitochondria were treated with swelling buffer $\left(120 \mathrm{mM} \mathrm{KCl}, 5 \mathrm{mM} \mathrm{KH} \mathrm{PO}_{4}, 20 \mathrm{mM}\right.$ MOPS, and $10 \mathrm{mM}$ Tris- $\mathrm{HCl}$ (pH 7.4)). The mPTP open level was assessed using a $\mathrm{Ca}^{2+}$-induced mitochondria swelling assay [19]. After adding $200 \mu \mathrm{M} \mathrm{CaCl}_{2}$ to the mitochondria, the opening of the mitochondrial permeability transition pore leads to mitochondrial swelling causing a stable decline in mitochondrial optical density. Due to the ability of the mitochondria to dilate, optical density (OD) was recorded using a microplate reader at $520 \mathrm{~nm}$ (BioRad 680, USA). Mitochondrial swelling was recorded as the optical density $\left(\mathrm{OD}_{1}\right)$ at $520 \mathrm{~nm}$, and a second optical density $\left(\mathrm{OD}_{2}\right)$ was recorded $20 \mathrm{~min}$ after induction. The optical density at $520 \mathrm{~nm}$ was continuously recorded over 20 min. mPTP activity was calculated as $\triangle \mathrm{OD}\left(\mathrm{OD}_{1}-\mathrm{OD}_{2}\right) /$ $\min \times 1000$.

2.10. Measurement of Caspase-3 Activity. Caspase-3 activity was measured using a caspase- 3 activity assay kit (Beyotime, Shanghai, China) following the manufacturer's instructions. H9c2 cells were lysed in lysis buffer on ice for $15 \mathrm{~min}$ and then collected and centrifuged at $16,000 \mathrm{~g}$ for $15 \mathrm{~min}$ at $4^{\circ} \mathrm{C}$ to obtain the supernatant. Protein concentration was determined using the bicinchoninic acid (BCA) protein assay kit (Beyotime, Shanghai, China). After adding detection buffer and Ac-DEVD-pNA and incubating at $37^{\circ} \mathrm{C}$ for $18 \mathrm{~h}$, optical density was detected at $405 \mathrm{~nm}$. Caspase-3 activity was measured using a microplate reader (Bio-Rad 680, USA). A.U. is the abbreviation for arbitrary units.

2.11. Analysis of Apoptosis by Flow Cytometry. We previously published methods for measuring apoptosis [20]. Briefly, apoptosis was assessed by flow cytometry using an Annexin V-FITC/PI apoptosis kit (KeyGEN BioTECH, Nanjing, China) following the manufacturer's instructions. Briefly, H9c2 cells were collected and washed three times with ice-cold PBS. Next, collected H9c2 cells were resuspended in $1 \mathrm{x}$ Binding Buffer at a final concentration of $5 \times$ $10^{5}$ cells $/ \mathrm{ml}$. After the addition of $5 \mu \mathrm{l}$ Annexin V-FITC and $5 \mu \mathrm{l} \mathrm{PI}, \mathrm{H} 9 \mathrm{c} 2$ cells were incubated in the dark for $15 \mathrm{~min}$ at room temperature. Cellular fluorescence was analysed by flow cytometry (ex $488 \mathrm{~nm}$; em $530 \mathrm{~nm}$, Beckman Coulter, USA).

2.12. Assessment of Apoptosis by TUNEL Staining. Apoptotic H9c2 cells were analysed by optical microscopy using the terminal deoxynucleotidyl transferase-mediated nick end labelling (TUNEL) staining method, which was performed using a TUNEL Apoptosis Detection kit (Promega, USA) [21]. Apoptotic H9c2 cells are stained brown, identifying them as TUNEL positive. Then, apoptotic H9c2 cells were subsequently observed on a microscope (Olympus, Japan). The number of TUNEL-positive H9c2 cells/the total number of $\mathrm{H} 9 \mathrm{c} 2$ cells represents the apoptotic index.

2.13. Statistical Analysis. All values are presented as the mean \pm SEM. ANOVA was applied to measure the significance of examined data across different groups, followed by post hoc analysis to determine individual differences. $p$ values $\leq 0.05$ were considered statistically significant.

\section{Results}

3.1. Pretreatment with VA Ameliorates the Viability of $\mathrm{H} 9 \mathrm{c} 2$ Cells and Reduces Levels of LDH and CPK in H9c2 Cells after $H / R$. To measure the effects of VA on H9c2 cells undergoing hypoxia/reoxygenation (H/R), MTS assay was performed on $\mathrm{H} 9 \mathrm{c} 2$ cells that were pretreated with different concentrations of VA $24 \mathrm{~h}$ prior to $\mathrm{H} / \mathrm{R}$. H9c2 cell viability decreased markedly in response to H/R (Figure $1(\mathrm{a}), p<0.01$ vs. control group). We demonstrated that VA significantly increased $\mathrm{H} 9 \mathrm{c} 2$ cell viability. Pretreatment with different concentrations of VA progressively increased viability of $\mathrm{H} 9 \mathrm{c} 2$ cell in a concentration-dependent manner. H9c2 cell viability peaked at $1.00 \mathrm{mM}$ VA ( $p<0.05$ vs. $0.50 \mathrm{mM} \mathrm{VA+H/R}$ group). However, H9c2 cells pretreated with concentrations of VA higher than $2.00 \mathrm{mM}$ exhibited a significant reduction in cell viability, illustrating that higher VA concentrations cause toxicity. Thus, $1.00 \mathrm{mM}$ VA was selected as the optimal pretreatment concentration for subsequent experiments. In addition, in Figure 1(b), our results show that AMPK $\alpha 2$-siRNA caused significantly reduced cell viability $(p<0.05$ vs. VA+H/R group). Thus, we hypothesized that VA protects $\mathrm{H} 9 \mathrm{c} 2$ cells from H/R injury through the AMPK signalling pathway.

To measure injury to $\mathrm{H} 9 \mathrm{c} 2$ cell membranes in response to $\mathrm{H} / \mathrm{R}$, we evaluated levels of $\mathrm{LDH}$ and CPK in the supernatant after H/R treatment. The levels of both $\mathrm{LDH}$ and CPK were increased in the H/R group ( $p<0.01$ vs. control group) and markedly decreased in the $\mathrm{VA}+\mathrm{H} / \mathrm{R}$ group $(p<0.01$ vs. $\mathrm{H} / \mathrm{R}$ group). Furthermore, the $\mathrm{VA}+\mathrm{AMPK} \alpha 2-\mathrm{siRNA}+\mathrm{H} / \mathrm{R}$ group significantly increased the levels of $\mathrm{LDH}$ and $\mathrm{CPK}$ $(p<0.01$ vs. VA+H/R group) (Figure 1(c)).

3.2. Pretreatment with VA Upregulates AMPK $\alpha 2$ Protein Levels in H9c2 Cells Undergoing H/R. To verify whether the AMPK $\alpha 2$ protein was associated with observed cardioprotective activity and optimal pretreatment concentration of VA, we assessed protein levels of AMPK $\alpha 2$ by western blot. We pretreated $\mathrm{H} 9 \mathrm{c} 2$ cells with different concentrations $(0.25$, 
\&

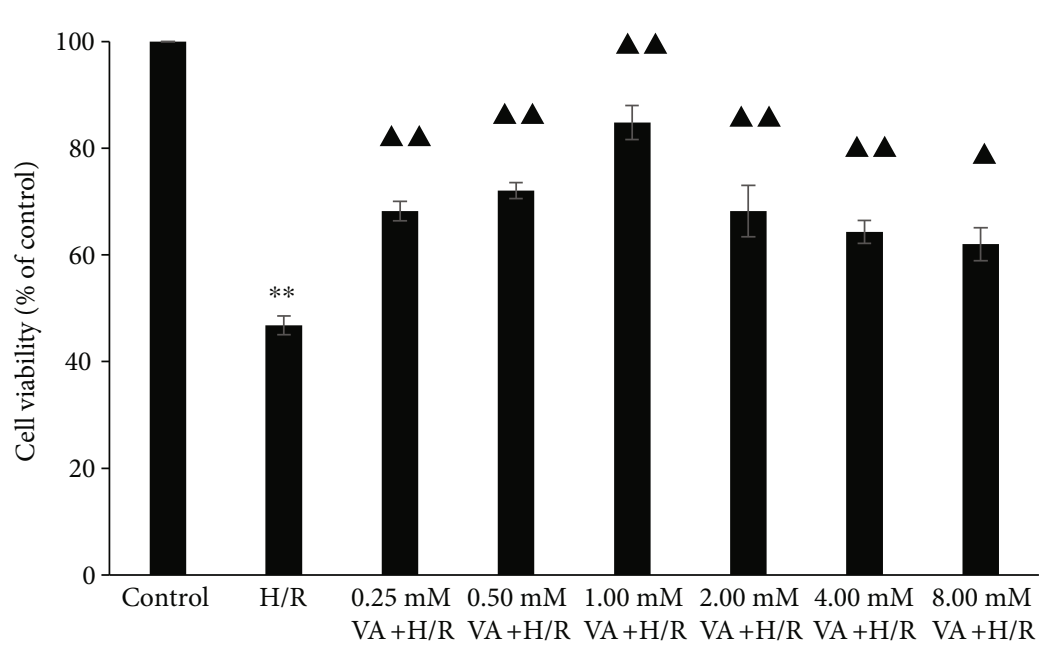

(a)

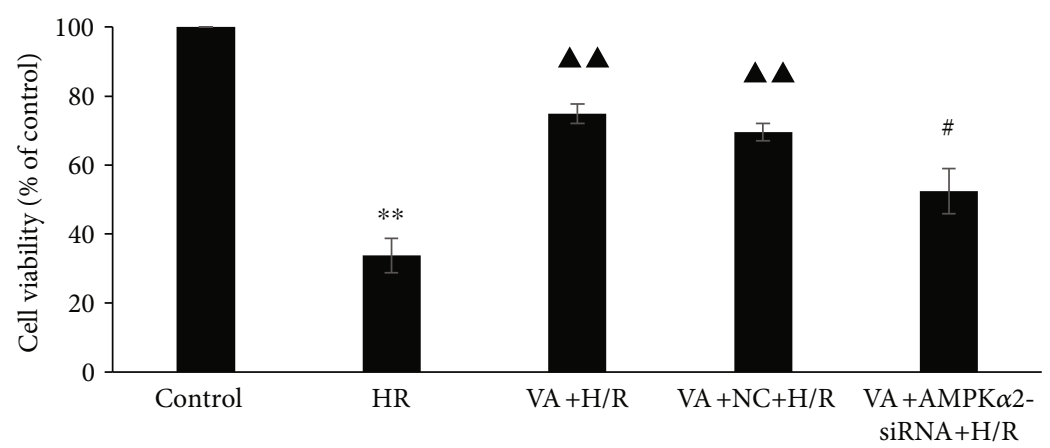

(b)

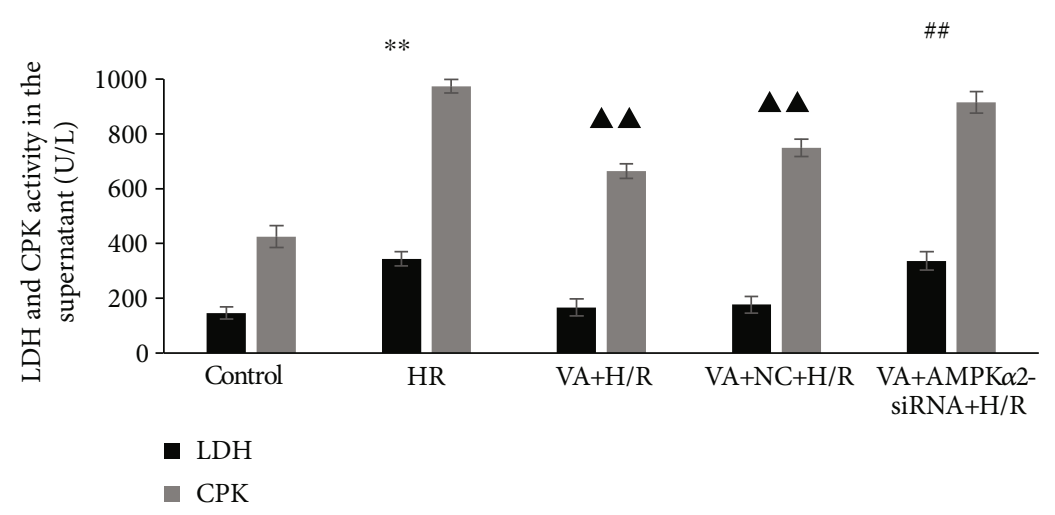

(c)

FIGURE 1: Effects of vanillic acid (VA) on the activities of creatine phosphate kinase (CPK) and lactate dehydrogenase (LDH) activities in the supernatant and cell viability in H9c2 cells subjected to hypoxia/reoxygenation (H/R) injury. (a) ${ }^{* *} p<0.01$ vs. control group; ${ }^{\mathbf{\Delta}} p<0.01$ vs. $\mathrm{H} / \mathrm{R}$ group; ${ }^{\boldsymbol{\Delta}} p<0.05$ vs. H/R group; ${ }^{\&} p<0.05$ vs. $0.50 \mathrm{mM} \mathrm{VA+H/R}$ group. (b) ${ }^{* *} p<0.01$ vs. control group; ${ }^{\boldsymbol{\Delta}} p<0.01$ vs. H/R group; ${ }^{\#} p<0.05$ vs. VA+H/R group. Data are expressed as the mean $\pm \mathrm{SEM}, n=3$. M: mol/l. (c) ${ }^{* *} p<0.01$ vs. control group; ${ }^{\wedge \mathbf{\Delta}} p<0.01$ vs. H/R group; $\# \#<0.01$ vs. VA+H/R group. Data are expressed as the mean $\pm \mathrm{SEM}, n=3$.

$0.50,1.00,2.00,4.00$, and $8.00 \mathrm{mM})$ of VA for $24 \mathrm{~h}$ before H/R. In Figure 2(a), most of VA-pretreated groups exhibited upregulated levels of $\mathrm{AMPK} \alpha 2$ protein relative to those of control and H/R groups, and the $1.00 \mathrm{mM} \mathrm{VA+H/R}$ group exhibited the highest levels of AMPK $\alpha 2$ protein $(p<0.05$ vs. $0.50 \mathrm{mM} V A+H / R$ group). The optimal pretreatment concentration was consistent with that observed by MTS. However, levels of AMPK $\alpha 2$ protein were markedly decreased in the $\mathrm{VA}+\mathrm{AMPK} \alpha 2$-siRNA $+\mathrm{H} / \mathrm{R}$ group relative to those in the VA+H/R group $(p<0.01)$ (Figure 2(b)). Thus, our data indicate that VA exhibits cardioprotective effects against $\mathrm{H} / \mathrm{R}$ by upregulating $\mathrm{AMPK} \alpha 2$ protein levels. 

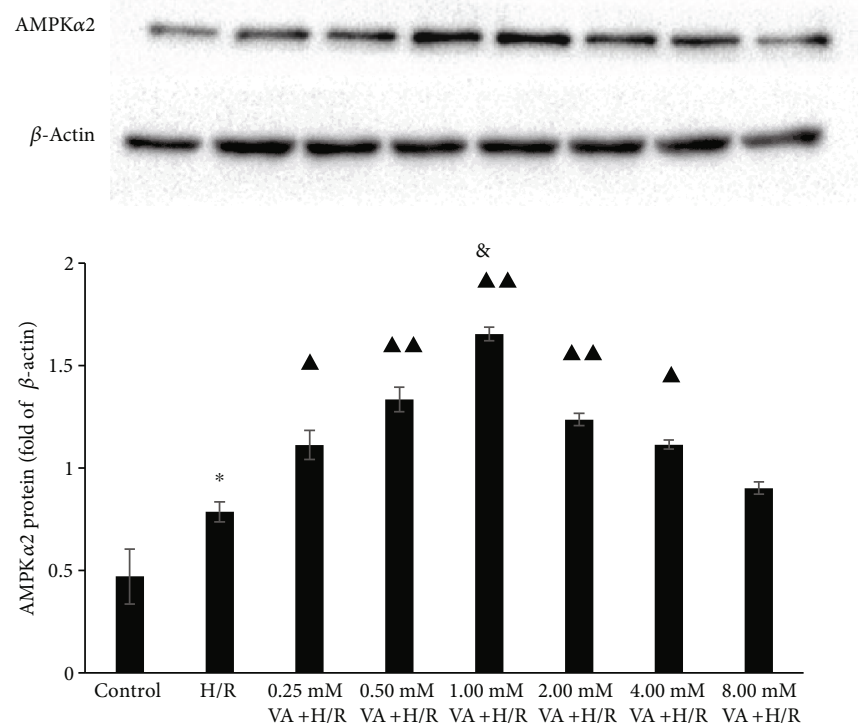

(a)

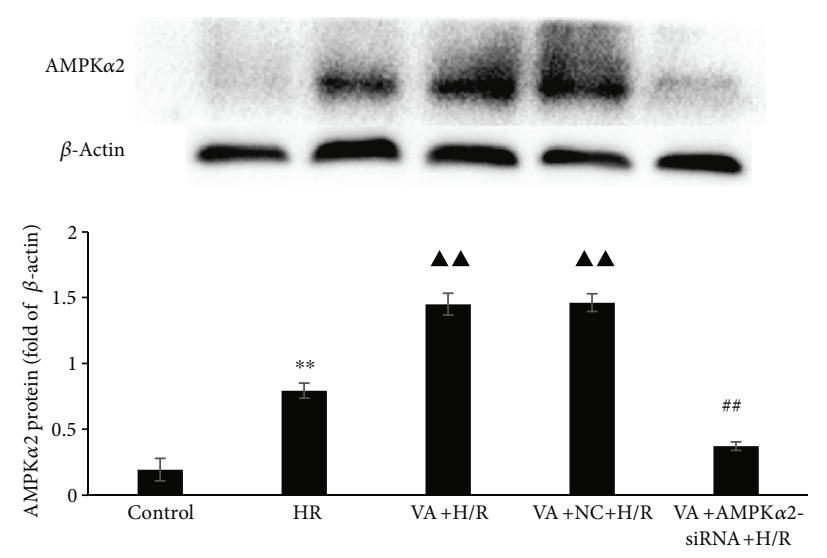

(b)

FIGURE 2: The effect of vanillic acid (VA) on the expression of AMPK $\alpha 2$ in H9c2 cells exposed to hypoxia/reoxygenation (H/R) injury. AMPK $\alpha 2$ expression was evaluated by western blot, and $\beta$-actin was used as an internal control. (a) ${ }^{*} p<0.05$ vs. control group; $\boldsymbol{\triangle}^{\mathbf{\Delta}} p<0.01$ vs. H/R group; ${ }^{\boldsymbol{\Delta}} p<0.05$ vs. H/R group; ${ }^{*} p<0.05$ vs. $0.50 \mathrm{mM} \mathrm{VA+H/R}$ group. (b) ${ }^{* *} p<0.01$ vs. control group; ${ }^{\boldsymbol{\Lambda}} p<0.01$ vs. H/R group; ${ }^{\# \#} p<0.01$ vs. VA+H/R group. Data are expressed as the mean $\pm \mathrm{SEM}, n=3$. M: mol/l.

3.3. Pretreatment with VA Reduces ROS Generation Induced by $H / R$. Relevant experiments were performed to evaluate ROS levels using the DCFH-DA fluorescence probe. ROS levels increased significantly in the H/R group $(p<0.01$ vs. control group), whereas there was a striking decrease in ROS levels in the $\mathrm{VA}+\mathrm{H} / \mathrm{R}$ and $\mathrm{VA}+\mathrm{NC}+\mathrm{H} / \mathrm{R}$ groups ( $p<0.01$ vs. H/R group). As expected, ROS levels markedly increased in the VA+AMPK $\alpha 2$-siRNA+H/R group $(p<$ 0.01 vs. $\mathrm{VA}+\mathrm{H} / \mathrm{R}$ group and $\mathrm{VA}+\mathrm{NC}+\mathrm{H} / \mathrm{R}$ group). These results confirmed that VA reduces ROS generation associated with the AMPK signalling pathway (Figure 3 ).

3.4. Pretreatment with VA Restores $\Delta \psi_{m}$ in H9c2 Cells Exposed to $H / R$. To determine $\Delta \psi_{\mathrm{m}}$ in $\mathrm{H} 9 \mathrm{c} 2$ cells after $\mathrm{H} / \mathrm{R}$ injury, a JC-1 fluorescent probe assay was performed. We used the fluorescence ratio of the upper right quadrant and lower right quadrant to verify $\Delta \psi_{\mathrm{m}}$. The results demon- strated that $\Delta \psi_{\mathrm{m}}$ decreased in response to $\mathrm{H} / \mathrm{R}(p<0.01$ vs. control group) (Figure 4). However, pretreatment with VA markedly reduced the loss of $\Delta \psi_{\mathrm{m}}$ in the $\mathrm{VA}+\mathrm{H} / \mathrm{R}$ group ( $p<0.01$ vs. H/R group). In contrast, a disruption in $\Delta \psi_{\mathrm{m}}$ was observed when the AMPK $\alpha 2$ gene was knocked down ( $p<0.01$ vs. $\mathrm{VA}+\mathrm{H} / \mathrm{R}$ group), demonstrating that AMPK $\alpha 2$ siRNA effectively abrogates the cardioprotective effects of VA against $H / R$ injury.

3.5. Pretreatment with VA Prevents Opening of the MPTP Induced by $H / R$. $\mathrm{Ca}^{2+}$-induced mitochondria swelling was used to examine the effects of VA on mPTP opening. We determined the degree of $\mathrm{mPTP}$ opening by recording varied optical density values at $520 \mathrm{~nm} / \mathrm{min}(\mathrm{OD} / \mathrm{min})$ over a period of time. As shown in Figure 5, there was a significant increase in $\Delta \mathrm{OD} / \mathrm{min}$ in the $\mathrm{H} / \mathrm{R}$ group ( $p<0.01$ vs. control group); however, pretreatment of $\mathrm{H} 9 \mathrm{c} 2$ cells with VA delayed mPTP 


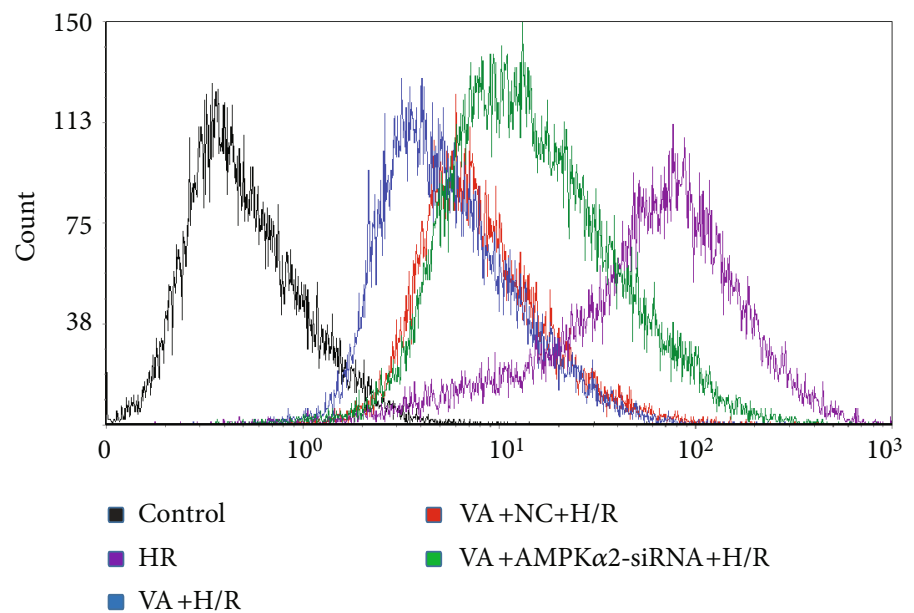

(a)

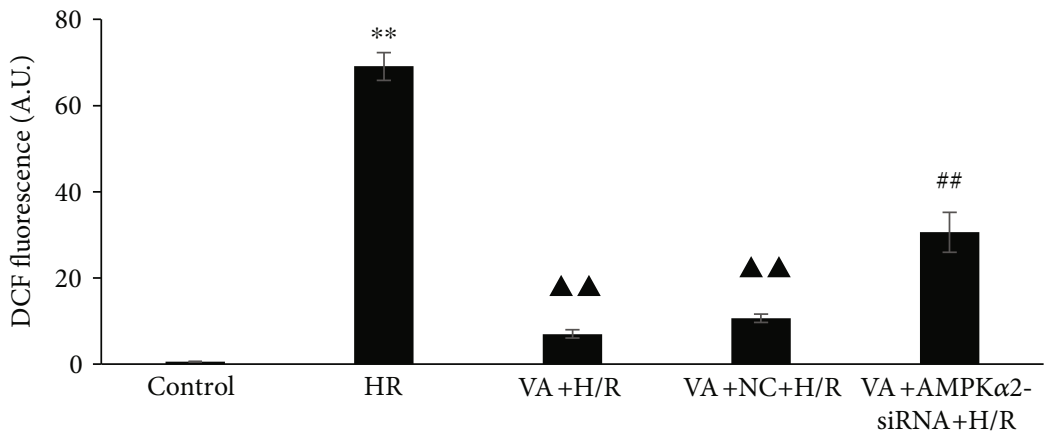

(b)

Figure 3: Vanillic acid (VA) pretreatment decreases ROS production in H9c2 cells exposed to hypoxia/reoxygenation (H/R). (a) Flow cytometry analysis of DCF fluorescence. (b) Column bar graph of cell fluorescence for DCF. Data are expressed as the mean \pm SEM, $n=3$. ${ }^{* *} p<0.01$ vs. control group; ${ }^{\mathbf{\Lambda}} p<0.01$ vs. H/R group; ${ }^{\# \#} p<0.01$ vs. VA+H/R group. A.U. is the abbreviation for arbitrary unit.

opening ( $p<0.01$ vs. H/R group). AMPK $\alpha 2$ gene knockdown using AMPK $\alpha 2$-siRNA lentivirus abolished the cardioprotective effects of VA against H/R injury with respect to inhibiting $\mathrm{mPTP}$ opening ( $p<0.05$ vs. $\mathrm{VA}+\mathrm{H} / \mathrm{R}$ group).

3.6. Pretreatment with VA Attenuates Caspase-3 Activity in response to $H / R$. To examine the cardioprotective effects of VA on H/R-induced injury, levels of caspase- 3 activity were estimated using a colorimetric method. Figure 6 shows a significant increase in caspase- 3 activity in the H/R group ( $p<0.01$ vs. control group), yet VA pretreatment strikingly decreased caspase- 3 activity ( $p<0.01$ vs. H/R group). Furthermore, in line with previous results, a significant increase in caspase- 3 activity was observed in the VA+AMPK $\alpha 2$ siRNA+H/R group ( $p<0.01$ vs. VA+H/R group).

3.7. Pretreatment with VA Decreases H9c2 Cell Apoptosis in response to $H / R$. Apoptosis was assessed by flow cytometry using an Annexin V-FITC/PI apoptosis kit. As shown in Figure 7, H9c2 cell apoptotic rates increased markedly in the H/R group ( $p<0.01$ vs. control group), while progressively decreasing in the $\mathrm{VA}+\mathrm{H} / \mathrm{R}$ group $(p<0.01$ vs. $\mathrm{H} / \mathrm{R}$ group). Moreover, $\mathrm{H} 9 \mathrm{c} 2$ cell apoptotic rates increased again in the VA+AMPK $\alpha 2-s i R N A+H / R$ group $(p<0.01$ vs. $\mathrm{VA}+\mathrm{H} / \mathrm{R}$ group).
To further confirm the VA-induced cardioprotective effect against $\mathrm{H} / \mathrm{R}$ injury, we scored the number of TUNEL-positive H9c2 cells by optical microscopy. As shown in Figure 8, H/R caused a significant increase in the number of TUNEL-positive H9c2 cells in the H/R group ( $p<0.01$ vs. control group). In contrast, the pretreatment of $\mathrm{H} 9 \mathrm{c} 2$ cells with VA resulted in significantly reduced TUNEL-positive $\mathrm{H} 9 \mathrm{c} 2$ cells $(p<0.01$ vs. H/R group). In agreement with previous results, the cardioprotective effects of VA were abrogated after AMPK $\alpha 2$ gene knockdown using the AMPK $\alpha 2$-siRNA lentivirus.

\section{Discussion}

Vanillic acid (VA) is a phenolic compound in edible plants that is enriched in the roots of Angelica sinensis. VA exhibits powerful antioxidant functions and possesses cardioprotective, antihypotensive, antiapoptotic, and hepatoprotective activities [8-11]. Experimental studies have provided evidence of this compound's efficacy in cardiac toxicity.

In this study, we found that $\mathrm{H} 9 \mathrm{c} 2$ cells pretreated with $1.00 \mathrm{mM}$ VA $24 \mathrm{~h}$ prior to H/R significantly increased the viability of $\mathrm{H} 9 \mathrm{c} 2$ cells and reduced the levels of $\mathrm{LDH}$ and CPK. And our data further confirmed VA pretreatment 
Control

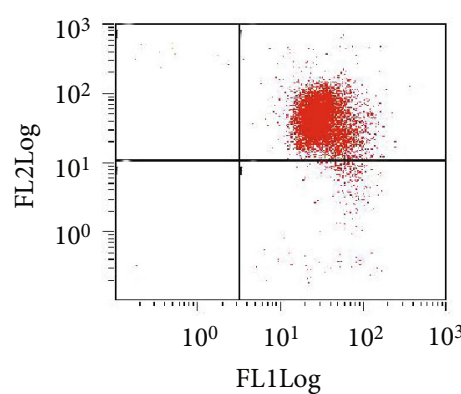

$\mathrm{VA}+\mathrm{AMPK} \alpha 2$-siRNA+H/R

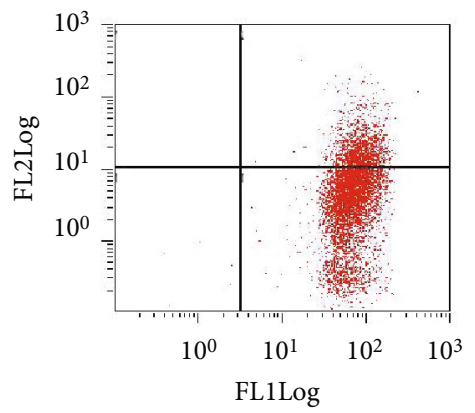

$\mathrm{VA}+\mathrm{NC}+\mathrm{H} / \mathrm{R}$

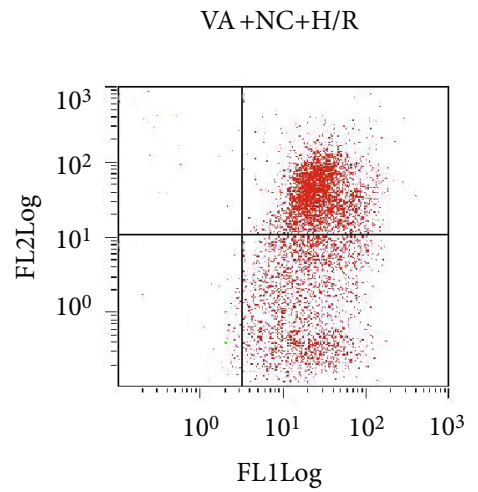

(a)

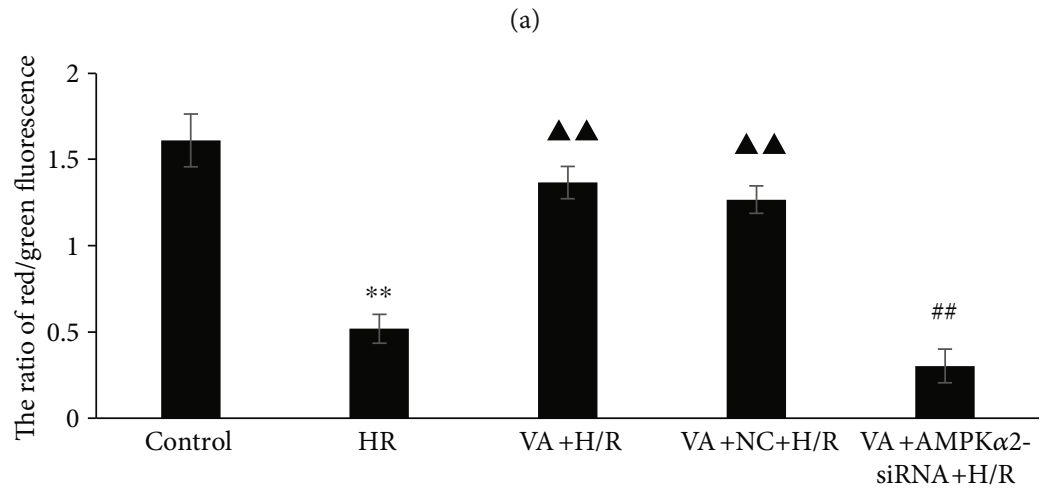

(b)
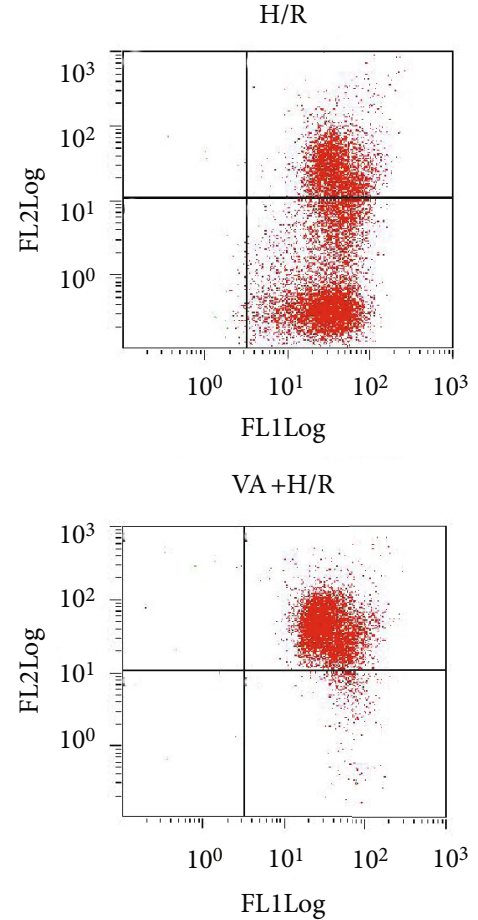

FIGURE 4: Vanillic acid (VA) pretreatment alleviates loss of $\Delta \Psi_{\mathrm{m}}$ in H9c2 cells exposed to hypoxia/reoxygenation (H/R), while AMPK $\alpha 2$ siRNA abrogates this effect. (a) Representative dot plots of flow cytometry. (b) $\Delta \Psi_{\mathrm{m}}$ was calculated with the ratio of red/green fluorescence obtained by flow cytometry. The ratio of fluorescence in the upper right quadrant and lower right quadrant was used to evaluate levels of $\Delta \Psi_{\mathrm{m}}$. Data are expressed as the mean \pm SEM, $n=3 .{ }^{* *} p<0.01$ vs. control group; ${ }^{\mathbf{\Delta}} p<0.01 \mathrm{vs.} \mathrm{H/R}$ group; ${ }^{\# \#} p<0.01$ vs. VA+H/R group. JC-1 FL1: JC-1 fluorescence channel 1; JC-1 FL2: JC-1 fluorescence channel 2. 


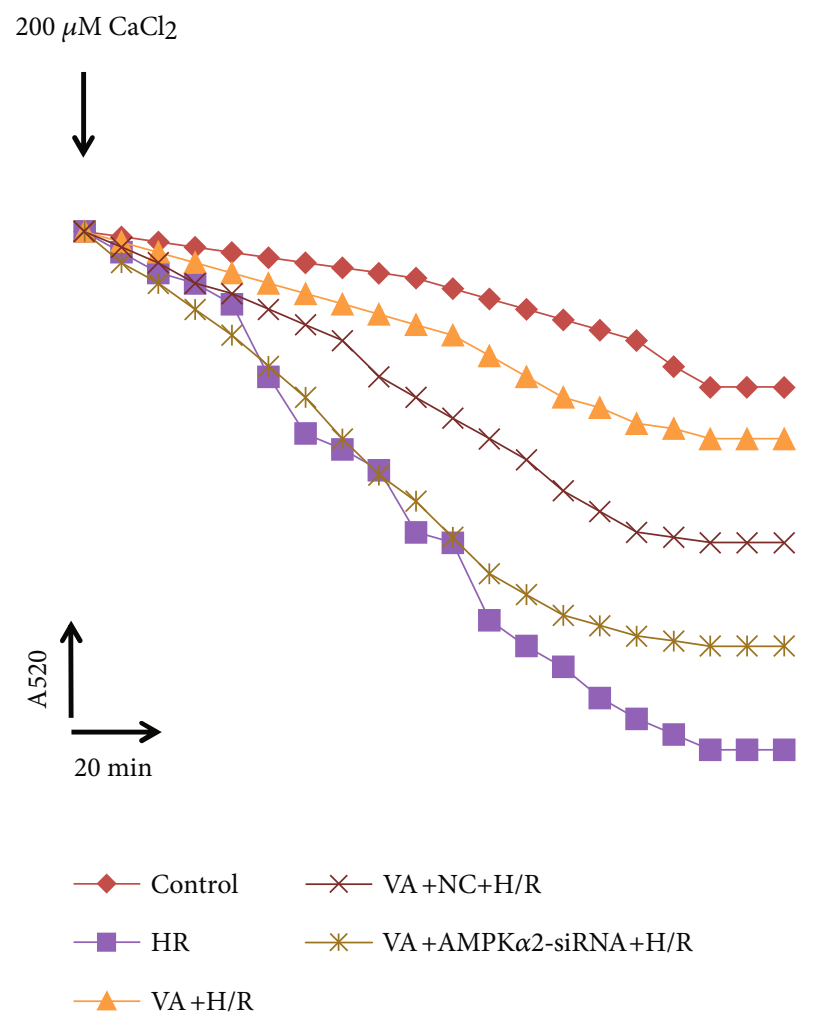

(a)

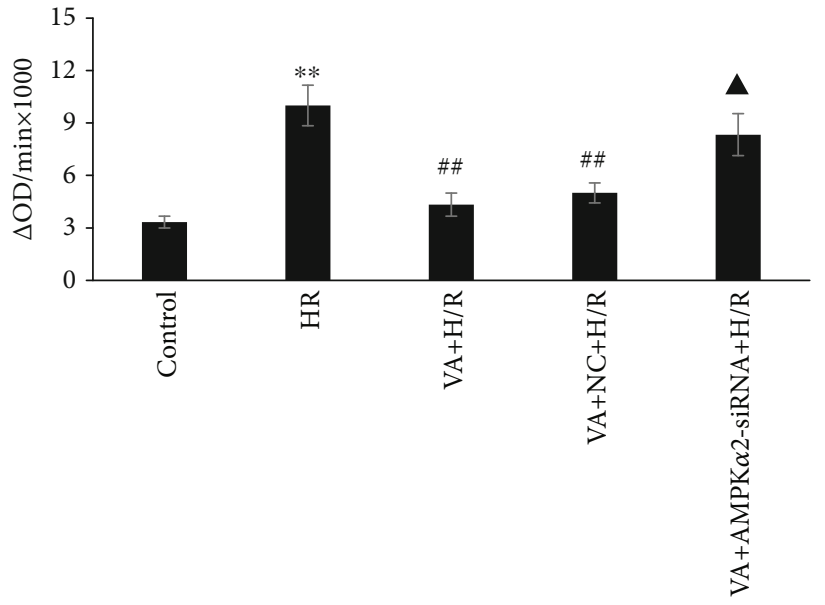

(b)

FIGURE 5: Vanillic acid (VA) preconditioning limited mPTP opening in response to hypoxia/reoxygenation (H/R) in H9c2 cells, while AMPK $\alpha 2$-siRNA attenuates this effect. (a) After the addition of $200 \mu \mathrm{M} \mathrm{CaCl}_{2}$, the absorbance value at A520 was monitored over 20 min to reflect the opening of mitochondrial permeability transition pore $(\mathrm{mPTP})$. (b) Changes in absorbance values at $520 \mathrm{~nm} / \mathrm{min}$ $\left(\Delta \mathrm{ODmin}^{-1}\right)$ were used to express the extent of $\mathrm{mPTP}$ opening $\left(\triangle \mathrm{OD}=\mathrm{A} 520_{0}\right.$ min $-\mathrm{A} 520_{20}$ min $)$. Data are expressed as the mean $\pm \mathrm{SEM}$, $n=3 .{ }^{* *} p<0.01$ vs. control group; ${ }^{\# \#} p<0.01$ vs. H/R group; ${ }^{*} p<0.05$ vs. VA+H/R group.

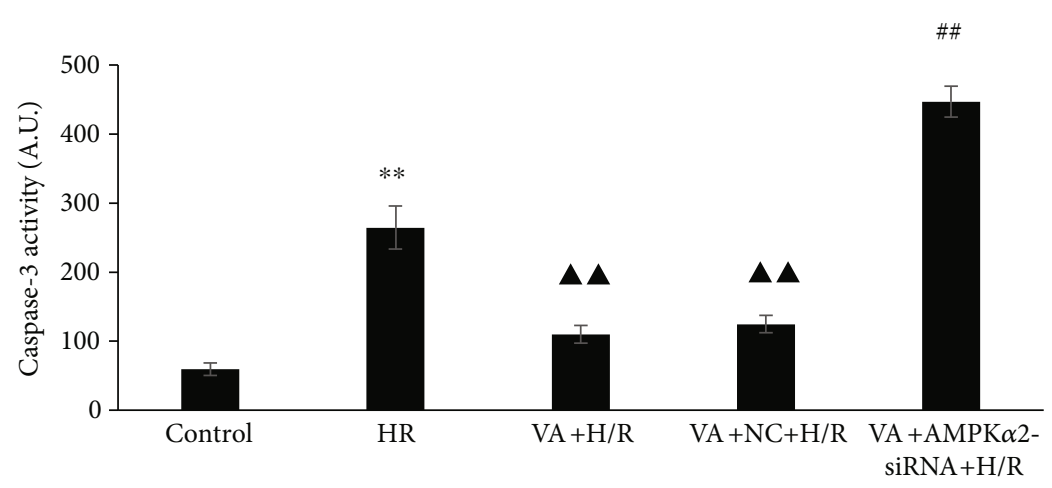

Figure 6: Vanillic acid (VA) pretreatment influences the activity of caspase-3 induced by hypoxia/reoxygenation (H/R) injury, while AMPK $\alpha 2$-siRNA abrogates this effect. The column bar graph represents the activity of caspase-3 in the different groups. Data are expressed as the mean \pm SEM, $n=3$. ${ }^{* *} p<0.01$ vs. control group; ${ }^{\boldsymbol{\Lambda}}{ }^{*} p<0.01$ vs. H/R group; ${ }^{\# \#} p<0.01$ vs. VA+H/R group. A.U. is the abbreviation for absorbance unit.

could inhibit cardiomyocyte apoptosis and protect them against $\mathrm{H} / \mathrm{R}$ injury.

The cardioprotective effect of VA was extensively investigated, and the potential mechanisms might be associated with countering oxidative stress caused by energy metabolism imbalance, but the mechanism remains to be fully elucidated. AMPK plays an important role in the balance of energy dynamics and is implicated in various diseases [22]. Studies including those from our group have shown that AMPK may be an oxidative stress sensor and redox regulator in addition to its traditional role as an energy sensor and regulator [23, 24]. Moreover, AMPK activation is believed to enhance cellular antioxidant capacity $[25,26]$. These findings all led us to hypothesize that VA protects $\mathrm{H} 9 \mathrm{c} 2$ cells against 
Control

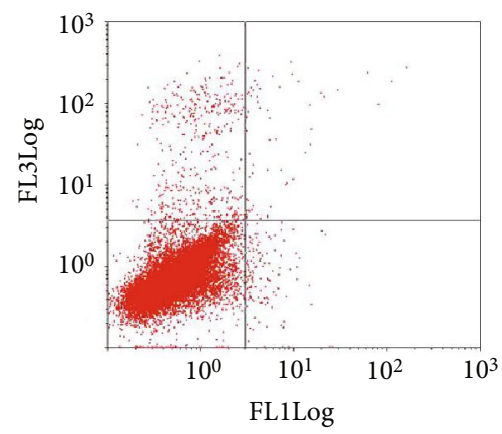

$\mathrm{VA}+\mathrm{H} / \mathrm{R}$

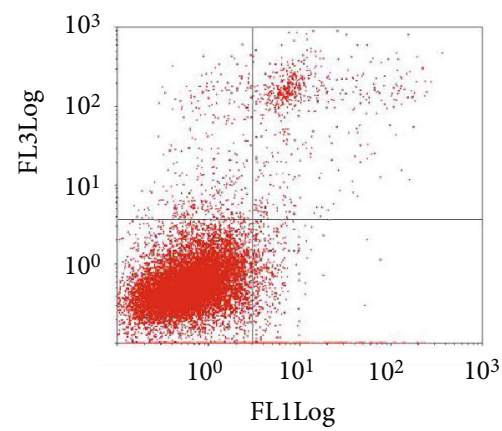

$\mathrm{VA}+\mathrm{AMPK} \alpha 2-\mathrm{siRNA}+\mathrm{H} / \mathrm{R}$

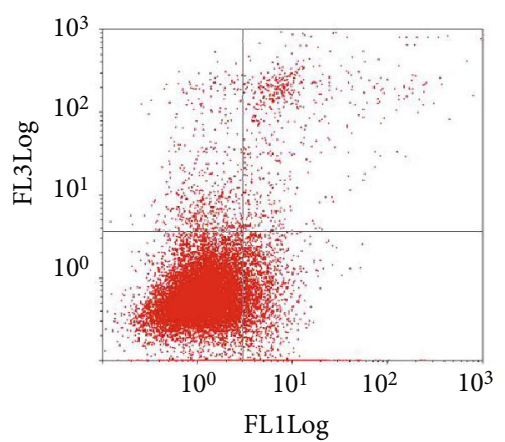

HR

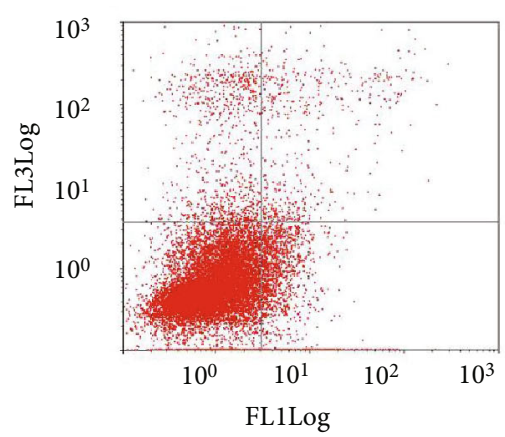

$\mathrm{VA}+\mathrm{NC}+\mathrm{H} / \mathrm{R}$

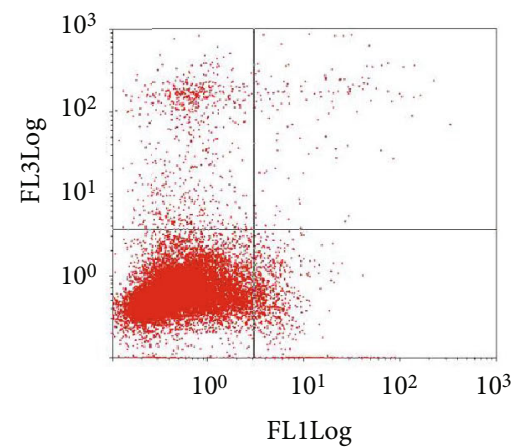

(a)

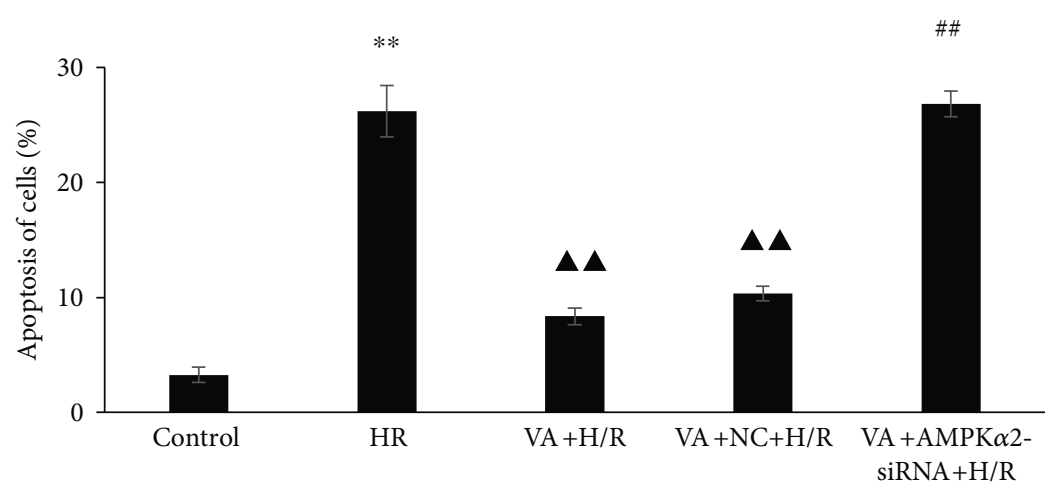

(b)

Figure 7: Vanillic acid (VA) pretreatment inhibits apoptosis in H9c2 cells exposed to hypoxia/reoxygenation (H/R), while AMPK $\alpha 2$-siRNA abrogates this effect. (a) Representative dot plots of flow cytometry ( $x$-axis and $y$-axis represent Annexin V and PI staining, respectively). (b) Evaluation of apoptotic cell populations. Data are expressed as the mean $\pm \mathrm{SEM}, n=3 .^{* *} p<0.01$ vs. control group; ${ }^{\boldsymbol{\Lambda}} p<0.01 \mathrm{vs}$. H/R group; $\#$ \# $p<0.01$ vs. $\mathrm{VA}+\mathrm{H} / \mathrm{R}$ group. 
Control

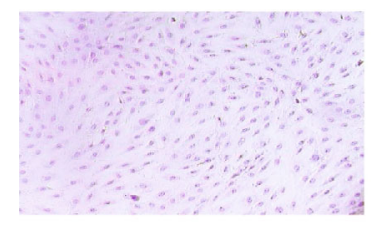

$\mathrm{VA}+\mathrm{H} / \mathrm{R}$

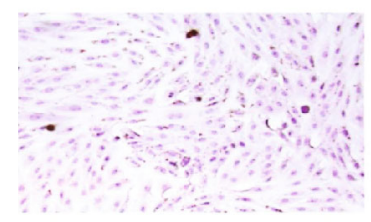

$\mathrm{VA}+\mathrm{AMPK} \alpha 2-\operatorname{siRNA}+\mathrm{H} / \mathrm{R}$

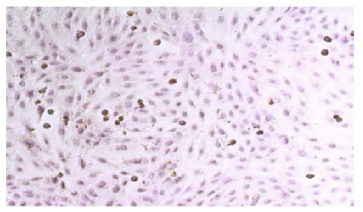

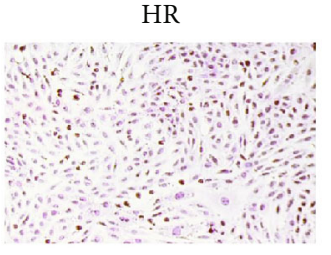

$\mathrm{VA}+\mathrm{NC}+\mathrm{H} / \mathrm{R}$

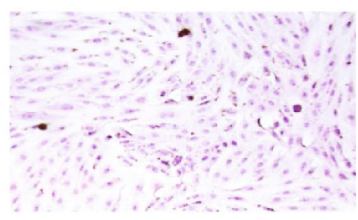

(a)

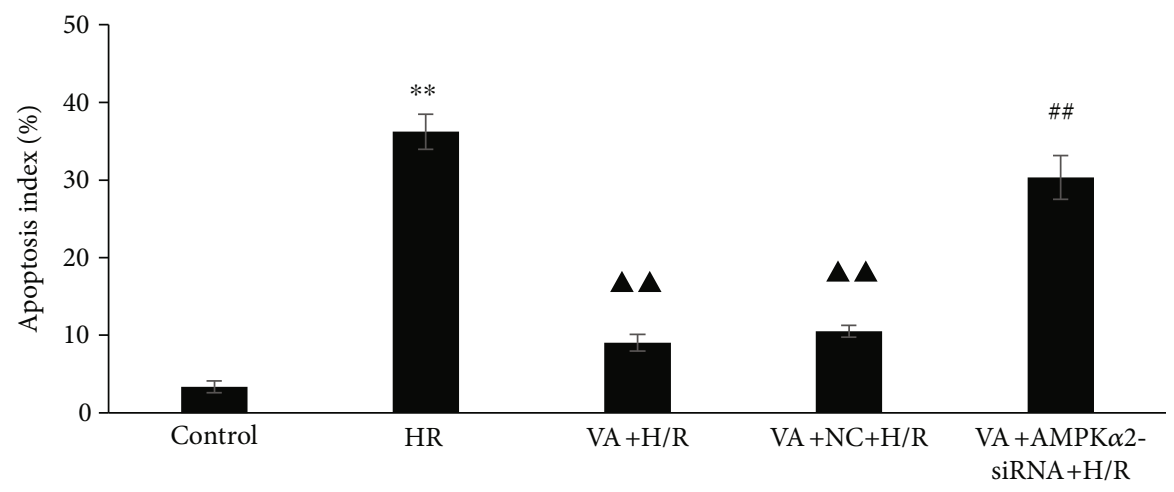

(b)

FIGURE 8: Vanillic acid (VA) pretreatment inhibits apoptosis in H9c2 cells exposed to hypoxia/reoxygenation (H/R), while AMPK $\alpha 2$-siRNA abrogates this effect. (a) H9c2 cells were sectioned and analysed for apoptosis using TUNEL staining. The panels show representative histological images. (b) The number of apoptotic cells evaluated by TUNEL is expressed as a percentage. Data are expressed as the mean \pm $\mathrm{SEM}, n=3 .{ }^{* *} p<0.01$ vs. control group; ${ }^{\mathbf{\Delta}} p<0.01$ vs. H/R group; ${ }^{\# \#} p<0.01$ vs. VA+H/R group.

H/R injury through antioxidant stress mediated by the AMPK signalling pathway. Therefore, we attempted to detect the expression level of AMPK $\alpha 2$ in the treatment of $\mathrm{H} 9 \mathrm{c} 2$ anti-H/R injury with different concentrations of vanillic acid and found that the expression level trend of AMPK $\alpha 2$ was consistent with the concentration trend of vanillic acid against H/R injury, as shown in Figures 1 (a) and 2(a). H9c2 cells pretreated with $1.00 \mathrm{mM}$ VA $24 \mathrm{~h}$ before H/R exhibited the highest AMPK $\alpha 2$ protein levels. AMPK $\alpha 2$ is known to be sensitive to hypoxia and can be activated by increases in AMP. Once H9c2 cells are subjected to H/R damage, they inevitably increase the expression of the AMPK $\alpha 2$ protein as an emergency response. However, the increase in $A M P K \alpha 2$ protein levels induced by $H / R$ damage is very limited and does not have a protective effect. Our results showed that vanillic acid induces $\mathrm{H} 9 \mathrm{c} 2$ cells to produce large quantities of $\mathrm{AMPK} \alpha 2$ protein and plays a protective role against H/R injury (Figures 1 and 2 ). So in the follow- ing studies, we focused on whether the protective effect of VA against H/R injury was associated with AMPK $\alpha 2$.

To verify whether the AMPK $\alpha 2$ protein was associated with the cardioprotective activity induced by vanillic acid, we used knockdown of AMPK $\alpha 2$ by its specific siRNA. In the recent years, a number of siRNAs have been successfully used in experimental models [27-29]. We specifically suppressed AMPK $\alpha 2$ expression using RNA interference, which selectively silenced gene expression by delivering double-stranded RNA molecules into cells, and western blot analysis showed that the expression of target protein AMPK $\alpha 2$ could be reduced, as shown in Figure 2(b). Once the expression of AMPK $\alpha 2$ was inhibited, the protective effect of vanillic acid pretreatment against $\mathrm{H} / \mathrm{R}$ injury in $\mathrm{H} 9 \mathrm{c} 2$ cells was eliminated. These findings confirmed that VA-induced cardioprotective effects on $\mathrm{H} / \mathrm{R}$ are associated with the AMPK $\alpha 2$ signalling pathway.

Electron transport chain injury results in the production of mitochondrial ROS and oxidative stress damage due to 
anoxia/reoxygenation [30]. ROS bursts lead to MPTP opening and trigger cellular energetic signals in response to ATP depletion and alterations in ion dynamic balance, ultimately resulting in plasma membrane breach and cell death [31, 32]. It has been demonstrated that $\mathrm{MPTP}$ is the central factor in different preconditioning protective mechanisms, and mPTP opening is thought to be important in the interim reperfusion injury [33]. H9c2 cells exposed to H/R injury demonstrated the increased production of ROS, the opening of the mPTP, and the loss of $\Delta \Psi_{\mathrm{m}}$. In contrast, pretreatment with VA attenuated ROS production, the opening of the mPTP, and the loss of $\Delta \Psi_{\mathrm{m}}$.

Oxidative stress damage results in a cellular apoptotic signalling cascade [34]. Caspase-3 is one of the key effectors in this mitochondria-mediated apoptosis pathway. The results showed increased caspase-3 activity in response to H/R injury. In contrast, pretreatment with VA attenuated this effect. Furthermore, pretreatment with VA markedly decreased apoptosis in response to $H / R$ injury in $H 9 c 2$ cells. To further verify the protective effect of VA against H/R-induced injury, the apoptosis was detected using two methods. The apoptosis results of flow cytometry and TUNEL were consistent, indicating that VA significantly protects $\mathrm{H} 9 \mathrm{c} 2$ cells exposed to $\mathrm{H} / \mathrm{R}$. It is noteworthy that the protective effect of VA disappeared in response to AMPK $\alpha 2$ downregulation.

Our study has proven that VA protects $\mathrm{H} 9 \mathrm{c} 2$ cells against $\mathrm{H} / \mathrm{R}$-induced injury via reducing the generation of ROS, stabilizing mitochondrial membrane potential, limiting the opening of mPTP, decreasing caspase-3 activity, and ultimately inhibiting cardiomyocyte apoptosis. Furthermore, all protective effects were abrogated by the knockdown of AMPK $\alpha 2$-siRNA. Therefore, our findings confirm that VAinduced cardioprotective effects on H/R injury are associated with the AMPK $\alpha 2$ protein.

\section{Data Availability}

Interested readers can reproduce our results by using our algorithm.

\section{Conflicts of Interest}

The authors report no conflicts of interests.

\section{Authors' Contributions}

Xiuya Yao and Shoufeng Jiao contributed equally to this work.

\section{Acknowledgments}

This work was supported by the Natural Science Foundation of China (Nos. 81460551, 81760587, 81460371, and 81760731), the Graduate Student Innovation Special Foundation of Nanchang University (No. cx2016299), and the Jiangxi Province Technology Support and Social Development Projects (No. 2010BSA13900).

\section{References}

[1] X. He, S. Li, B. Liu et al., "Major contribution of the 3/6/7 class of TRPC channels to myocardial ischemia/reperfusion and cellular hypoxia/reoxygenation injuries," Proceedings of the National Academy of Sciences of the United States of America, vol. 114, no. 23, pp. E4582-E4591, 2017.

[2] W. Zheng and S. Y. Wang, "Antioxidant activity and phenolic compounds in selected herbs," Journal of Agricultural and Food Chemistry, vol. 49, no. 11, pp. 5165-5170, 2001.

[3] W. R. Russell, L. Scobbie, A. Labat, and G. G. Duthie, "Selective bio-availability of phenolic acids from Scottish strawberries," Molecular Nutrition \& Food Research, vol. 53, Suppplement 1, pp. S85-S91, 2009.

[4] M. Gitzinger, C. Kemmer, D. A. Fluri, M. Daoud el-Baba, W. Weber, and M. Fussenegger, "The food additive vanillic acid controls transgene expression in mammalian cells and mice," Nucleic Acids Research, vol. 40, no. 5, article e37, 2012.

[5] H. I. Jun, G. S. Song, E. I. Yang, Y. Youn, and Y. S. Kim, "Antioxidant activities and phenolic compounds of pigmented rice bran extracts," Journal of Food Science, vol. 77, no. 7, pp. C759-C764, 2012.

[6] H. Palafox-Carlos, E. M. Yahia, and G. A. González-Aguilar, "Identification and quantification of major phenolic compounds from mango (Mangifera indica, cv. Ataulfo) fruit by HPLC-DAD-MS/MS-ESI and their individual contribution to the antioxidant activity during ripening," Food Chemistry, vol. 135, no. 1, pp. 105-111, 2012.

[7] V. G. Alves, A. G. Souza, L. U. R. Chiavelli et al., "Phenolic compounds and anticancer activity of commercial sugarcane cultivated in Brazil," Anais da Academia Brasileira de Ciências, vol. 88, no. 3, pp. 1201-1209, 2016.

[8] A. Itoh, K. Isoda, M. Kondoh et al., "Hepatoprotective effect of syringic acid and vanillic acid on concanavalin a-induced liver injury," Biological \& Pharmaceutical Bulletin, vol. 32, no. 7, pp. 1215-1219, 2009.

[9] T. H. Chou, H. Y. Ding, W. J. Hung, and C. H. Liang, "Antioxidative characteristics and inhibition of alpha-melanocytestimulating hormone-stimulated melanogenesis of vanillin and vanillic acid from Origanum vulgare," Experimental Dermatology, vol. 19, no. 8, pp. 742-750, 2010.

[10] S. Kumar, P. Prahalathan, and B. Raja, "Antihypertensive and antioxidant potential of vanillic acid, a phenolic compound in L-NAME-induced hypertensive rats: a dose-dependence study," Redox Report, vol. 16, no. 5, pp. 208-215, 2011.

[11] P. S. Prince, K. Dhanasekar, and S. Rajakumar, "Preventive effects of vanillic acid on lipids, bax, bcl-2 and myocardial infarct size on isoproterenol-induced myocardial infarcted rats: a biochemical and in vitro study," Cardiovascular Toxicology, vol. 11, no. 1, pp. 58-66, 2011.

[12] V. G. Zaha, D. Qi, K. N. Su et al., "AMPK is critical for mitochondrial function during reperfusion after myocardial ischemia," Journal of Molecular and Cellular Cardiology, vol. 91, pp. 104-113, 2016.

[13] S. B. Wu, Y. T. Wu, T. P. Wu, and Y. H. Wei, "Role of AMPKmediated adaptive responses in human cells with mitochondrial dysfunction to oxidative stress," Biochimica et Biophysica Acta (BBA) - General Subjects, vol. 1840, no. 4, pp. 1331-1344, 2014.

[14] H. Huang, S. Lai, Q. Wan, W. Qi, and J. Liu, “Astragaloside IV protects cardiomyocytes from anoxia/reoxygenation injury by upregulating the expression of Hes1 protein," Canadian 
Journal of Physiology and Pharmacology, vol. 94, no. 5, pp. 542-553, 2016.

[15] T. Koyama, K. Temma, and T. Akera, "Reperfusion-induced contracture develops with a decreasing ${ }^{[\mathrm{Ca} 2+] \mathrm{i}}$ in single heart cells," American Journal of Physiology-Heart and Circulatory Physiology, vol. 261, no. 4, pp. H1115-H1122, 1991.

[16] M. Xu, Y. Wang, K. Hirai, A. Ayub, and M. Ashraf, "Calcium preconditioning inhibits mitochondrial permeability transition and apoptosis," American Journal of Physiology-Heart and Circulatory Physiology, vol. 280, no. 2, pp. H899-H908, 2001.

[17] D. Ren, X. Wang, T. Ha et al., "SR-A deficiency reduces myocardial ischemia/reperfusion injury; involvement of increased microRNA-125b expression in macrophages," Biochimica et Biophysica Acta (BBA) - Molecular Basis of Disease, vol. 1832, no. 2, pp. 336-346, 2013.

[18] M. Zhu, W. Deng, S. di, M. Qin, D. Liu, and B. Yi, "Gastrodin protects cardiomyocytes from anoxia/reoxygenation injury by

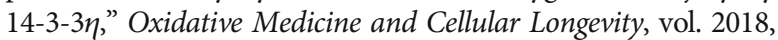
Article ID 3685391, 11 pages, 2018.

[19] Z. Guo, Z. Liao, L. Huang, D. Liu, D. Yin, and M. He, "Kaempferol protects cardiomyocytes against anoxia/reoxygenation injury via mitochondrial pathway mediated by SIRT1," European Journal of Pharmacology, vol. 761, pp. 245-253, 2015.

[20] D. Liu, B. Yi, Z. Liao et al., "14-3-3 $\gamma$ protein attenuates lipopolysaccharide-induced cardiomyocytes injury through the Bcl-2 family/mitochondria pathway," International Immunopharmacology, vol. 21, no. 2, pp. 509-515, 2015.

[21] Z. Liao, H. He, G. Zeng et al., "Delayed protection of Ferulic acid in isolated hearts and cardiomyocytes: upregulation of heat-shock protein 70 via NO-ERK1/2 pathway," Journal of Functional Foods, vol. 34, pp. 18-27, 2017.

[22] G. R. Steinberg and B. E. Kemp, "AMPK in health and disease," Physiological Reviews, vol. 89, no. 3, pp. 1025-1078, 2009.

[23] S. M. Jeon, "Regulation and function of AMPK in physiology and diseases," Experimental \& Molecular Medicine, vol. 48, no. 7, article e245, 2016.

[24] S. Wang, P. Song, and M. H. Zou, "AMP-activated protein kinase, stress responses and cardiovascular diseases," Clinical Science, vol. 122, no. 12, pp. 555-573, 2012.

[25] W. Sun, C. Yan, B. Frost et al., "Pomegranate extract decreases oxidative stress and alleviates mitochondrial impairment by activating AMPK-Nrf2 in hypothalamic paraventricular nucleus of spontaneously hypertensive rats," Scientific Reports, vol. 6, no. 1, article 34246, 2016.

[26] X. Han, H. Tai, X. Wang et al., "AMPK activation protects cells from oxidative stress-induced senescence via autophagic flux restoration and intracellular $\mathrm{NAD}^{+}$elevation," Aging Cell, vol. 15, no. 3, pp. 416-427, 2016.

[27] H. Dana, G. M. Chalbatani, H. Mahmoodzadeh et al., "Molecular mechanisms and biological functions of siRNA," International Journal of Biomedical Science, vol. 13, no. 2, pp. 48-57, 2017.

[28] Y. Ishibashi and Y. Hirabayashi, "AMP-activated protein kinase suppresses biosynthesis of glucosylceramide by reducing intracellular sugar nucleotides," Journal of Biological Chemistry, vol. 290, no. 29, pp. 18245-18260, 2015.

[29] X. Chen, X. Li, W. Zhang et al., "Activation of AMPK inhibits inflammatory response during hypoxia and reoxygenation through modulating JNK-mediated NF- $\kappa$ B pathway," Metabolism, vol. 83, pp. 256-270, 2018.
[30] W. J. Li, S. P. Nie, Y. Chen et al., "Ganoderma atrum polysaccharide protects cardiomyocytes against anoxia/reoxygenation-induced oxidative stress by mitochondrial pathway," Journal of Cellular Biochemistry, vol. 110, no. 1, pp. 191-200, 2010.

[31] E. J. Griffiths, "Mitochondria and heart disease," Advances in Experimental Medicine and Biology, vol. 942, pp. 249-267, 2012.

[32] D. B. Zorov, M. Juhaszova, and S. J. Sollott, "Mitochondrial reactive oxygen species (ROS) and ROS-induced ROS release," Physiological Reviews, vol. 94, no. 3, pp. 909-950, 2014.

[33] D. Morin, R. Assaly, S. Paradis, and A. Berdeaux, "Inhibition of mitochondrial membrane permeability as a putative pharmacological target for cardioprotection," Current Medicinal Chemistry, vol. 16, no. 33, pp. 4382-4398, 2009.

[34] N. Moorjani, S. Westaby, J. Narula et al., "Effects of left ventricular volume overload on mitochondrial and death-receptormediated apoptotic pathways in the transition to heart failure," The American Journal of Cardiology, vol. 103, no. 9, pp. 12611268, 2009. 